\title{
ZMIENNOŚĆ MODUŁU SPRĘŻYSTOŚCI BETONU W TRZONIE PALA PRZEMIESZCZENIOWEGO W ŚWIETLE BADAŃ LABORATORYJNYCH
}

\author{
Mateusz Wiszniewski ${ }^{1 凶}$, Adam Krasiński $^{1}$, Jan Linowiecki ${ }^{2}$ \\ ${ }^{1}$ Wydział Inżynierii Lądowej i Środowiska, Politechnika Gdańska, Gdańsk \\ ${ }^{2}$ Menard Polska
}

\begin{abstract}
STRESZCZENIE
W pracy przedstawiono problematykę dotyczącą określania właściwości materiałowych betonu w celu interpretacji wyników próbnych obciążeń pali oprzyrządowanych pomiarowo. Wykonano badania laboratoryjne modułu sprężystości betonu $\left(E_{b}\right)$ na poszczególnych sekcjach wydobytego z gruntu pala przemieszczeniowego. Określona została charakterystyka zmienności modułu wraz z odkształceniem i głębokością. Przetestowano 29 próbek z 5 różnych głębokości. W pracy zaprezentowane zostały metody szacowania rzeczywistej wartości modułu. Przedstawiony został również wpływ przyjętych parametrów betonu na interpretację próbnych obciążeń statycznych pali oprzyrządowanych pomiarowo.
\end{abstract}

Słowa kluczowe: moduł Younga betonu, pale fundamentowe, pomiar odkształceń, oprzyrządowanie pali

\section{WSTĘP}

Współpraca pali i fundamentów palowych z podłożem gruntowym jest jednym z bardziej złożonych zagadnień geotechnicznych. Złożone zjawiska fizyczne zachodzące $\mathrm{w}$ gruncie są dodatkowo komplikowane przez procesy technologiczne wykonania pala. Wykonywane są specjalne badania statyczne nośności pali oprzyrządowanych pomiarowo w celu pozyskania szczegółowych danych ilościowych na temat rozkładu naprężenia $\mathrm{w}$ gruncie i charakteru współpracy z palem poszczególnych warstw gruntu wzdłuż pobocznicy i pod podstawą. Do poprawnej analizy uzyskanych wyników niezbędne są pewne parametry wyjściowe. Oprzyrządowanie pala polega zazwyczaj na zamontowaniu czujników mierzących odkształcenia w rdzeniu pala wraz z jego przemieszczeniami. Obecnie najczęściej stosowane są tzw. czujniki ekstensometryczne, wykorzystujące technologię wibrującej struny, które zapewniają wysoki poziom dokładności $\sim 0.002 \mathrm{~mm}$ (Krasiński i Sieńko, 2010). Następnie na podstawie pomiaru odkształceń, a właściwie skróceń odcinków pomiarowych, stosując podstawowe prawo sprężystości materiału Hooke'a (1), można wyznaczyć przekrojowe siły osiowe występujące $\mathrm{w}$ trzonie pala.

$$
P=\varepsilon \cdot E \cdot A
$$

gdzie:

$P$ - siła osiowa (powodująca daną deformację) $[\mathrm{kN}]$;

$\varepsilon$ - osiowe odkształcenie trzonu [-];

$E$ - moduł sprężystości $\left[\mathrm{kN} \cdot \mathrm{m}^{-2}\right]$;

$A$ - pole powierzchni przekroju $\left[\mathrm{m}^{2}\right]$.

Zgodnie ze wspomnianym prawem, należy odpowiednio scharakteryzować badany materiał i przekrój pala. Wymagane są parametry opisujące sztywność tego materiału EA, czyli moduł sprężystości Younga $(E)$ oraz pole powierzchni przekroju $(A)$. Jeżeli mamy

\footnotetext{
${ }^{凶}$ mateusz.wiszniewski@pg.edu.pl
} 
Wiszniewski, M., Krasiński, A., Linowiecki, J. (2018). Zmienność modułu sprężystości betonu w trzonie pala przemieszczeniowego w świetle badań laboratoryjnych. Acta Sci. Pol. Architectura, 17 (3), 57-65. doi: 10.22630/ASPA.2018.17.3.29

do czynienia z palami zbrojonymi, zarówno moduł, jak i przekrój dotyczyć będą materiału zespolonego (beton i stal), co należy uwzględnić w analizie. W odniesieniu do stali moduł $E$ można oszacować z dużą dokładnością i przyjmuje się go jako wartość stałą. W palach prefabrykowanych, wielkośrednicowych, stalowych i wierconych w rurach osłonowych określenie sztywności jest znacznie łatwiejsze niż w palach wierconych bez rur osłonowych i wkręcanych (przemieszczeniowych), w przypadku których trudno jest jednoznacznie określić średnicę trzonu oraz jej ewentualną zmienność na długości. Prowadzone są badania jednorodności trzonu, badania ultrasonograficzne, mające wychwycić anomalnie, np. przewężenia lub nieciagłości, różna jest zaś ich dokładność i nie ma jednoznacznych metod określania średnicy pala bez jego wydobycia z gruntu. Niniejsza praca dotyczy drugiego parametru, tj. modułu sprężystości betonu $\left(E_{b}\right)$.

$\mathrm{Z}$ powodu braku dokładniejszych danych, moduł $E$ betonu jest często przyjmowany na podstawie tablic, opracowanych na podstawie deklarowanej przez producenta wytrzymałości na ściskanie, ewentualnie według wytrzymałości wyznaczonej z próbek pobranych podczas wykonywania pala (Ali i Lee, 2008). W pracy Krasińskiego (2011) wykazano, że środowisko oraz czas dojrzewania betonu wpływaja jednak na wartości modułu. Wyniki dla próbek dojrzewających w laboratorium oraz wyniki badań terenowych znacznie się od siebie różnią, więc nie jest to wiarygodna metoda. Obecnie moduł sprężystości jest najczęściej wyznaczany bezpośrednio w terenie podczas próbnego obciążenia pala. Czujniki odkształceń umieszczane są bezpośrednio pod głowicą pala, a grunt wokół jest usuwany (brak tarcia), co umożliwia czyste ściskanie trzonu przy dokładnie znanej sile. Na tej podstawie można określić współzależność naprężenia i odkształcenia, a następnie wartości modułu $E$. Pojawia się jednak wątpliwość, czy moduł będzie miał takie same wartości na całej długości pala. Dodatkowo powszechnie znana jest zależność modułu od odkształcenia (moduł maleje wraz z odkształceniem). Czy ta charakterystyka również będzie jednorodna?

Inną metodę wyznaczania modułu sprężystości in situ zaproponował Fellenius (1989), tzw. Tagent Modulus Method. Polega ona na pomiarze przyrostów od- kształceń na poszczególnych odcinkach pala podczas wykonywania próbnego obciążenia. Siła przyłożona do głowicy pala stopniowo maleje wraz z głębokością, gdyż jest częściowo równoważona przez opory tarcia na pobocznicy. Przy osiagnięciu maksymalnego (rezydualnego) oporu tarcia gruntu, kolejne przyrosty obciążenia są w całości przekazywane na trzon pala i generują odpowiednie przyrosty odkształcenia. $\mathrm{Na}$ podstawie analizy tych przyrostów oszacować można moduł sprężystości betonu. Metoda ta daje zadowalające rezultaty, umożliwia określenie modułu na danej głębokości oraz jego zmienności wraz z odkształceniem, ale niestety ma również kilka wad - jest skuteczna tylko przy osiagnięciu większych odkształceń na poszczególnych odcinkach pala (do ok. $500 \mu \varepsilon$ ) oraz znacznego przemieszczenia całego pala $\mathrm{w}$ celu osiagnięcia pełnej mobilizacji gruntu na pobocznicy, co jest trudne do uzyskania, zwłaszcza w dolnej części pala. Wymagana jest również stała prędkość przyrostu obciążenia (lub jednakowy czas poszczególnych kroków obciążenia).

Według Kiefera i Bakera (1994) są 2 czynniki, które moga przyczynić się do zmiany właściwości betonu wraz $\mathrm{z}$ głębokością. Pierwszym $\mathrm{z}$ nich jest technologia betonowania. Mieszanka może być zrzucana do otworu wiertniczego z poziomu terenu, co może spowodować większe zagęszczenie dolnych warstw, a więc lepsze parametry wytrzymałościowe. Gdy mieszanka betonowa podawana jest za pomocą świdra (z dołu do góry), teoretycznie kontrolowane jest ciśnienie mieszanki, możliwe jest jednak wystąpienie lokalnych osłabień spowodowanych poprzez niższe ciśnienie, np. ze względu na zwiększoną prędkość wyjmowania świdra, co może zajść przy przechodzeniu świdra przez warstwy gruntowe o odmiennych parametrach fizycznych. Drugi czynnik jest niezależny od technologii wykonania pala $\mathrm{w}$ terenie i polega na tym, że świeża mieszanka betonowa ze względu na swój ciężar bardziej zagęści się w głębszych partiach pala, co związane jest również z większym odpływem wody zarobowej do gruntu i wzrostem wskaźnika $c / w$. Justs, Bajare, Shakhmenko i Korjakins (2011) w swojej pracy wykazali, że nawet niewielkie ciśnienie może mieć znaczący wpływ na mechaniczne właściwości betonu. Amir, Amir i Lam (2014), analizując w swojej pracy pale o długości do 
Wiszniewski, M., Krasiński, A., Linowiecki, J. (2018). Zmienność modułu sprężystości betonu w trzonie pala przemieszczeniowego w świetle badań laboratoryjnych. Acta Sci. Pol. Architectura, 17 (3), 57-65. doi: 10.22630/ASPA.2018.17.3.29

$70 \mathrm{~m}$, wykazali przyrost modułu $E$ wraz z głębokością średnio o $78-85 \mathrm{MPa} \cdot \mathrm{m}^{-1}$. Ponadto moduł betonu jest uzależniony od warunków dojrzewania, m.in. od wysokości zwierciadła wody gruntowej. Jeśli beton podczas dojrzewania ma dostęp do wody, to osiagnie większe wartości parametrów wytrzymałościowych.

\section{ANALIZOWANE PALE PRZEMIESZCZENIOWE}

W ramach zadania badawczego wykonano dwa pale przemieszczeniowe wkręcane, oprzyrządowane pomiarowo, które po wykonaniu próbnych obciążeń statycznych, zostały wydobyte z gruntu w celu szczegółowego określenia średnicy i wycięcia próbek betonu do badania modułów sprężystości na poszczególnych odcinkach trzonów.

Pale oraz prace badawcze przeprowadzone zostały przy współpracy z firmą Menard na poletku doświadczalnym obok realizowanej $\mathrm{w}$ tym czasie budowy. Długość pali wynosiła: $5,55 \mathrm{~m}$ (pal A) oraz $5,45 \mathrm{~m}$ (pal B). Pale wykonano w odległości od siebie około $2 \mathrm{~m}$. Zastosowano beton klasy C30/37. Rozpoznano warunki gruntowe i przedstawiono je w formie wykresu sondowania CPT na rysunku 9. Do około 1,2 m p.p.t. znajdował się piasek średnio zagęszczony, nastepnie nawodniony namuł o słabych parametrach mechanicznych, a od około $4 \mathrm{~m}$ p.p.t. warstwa nośna ze średnio zagęszczonego piasku.

Pale wydobyto $\mathrm{z}$ gruntu po około 30 dniach od wykonania (rys. 1). Stwierdzono niewielkie przewężenia w obydwu palach (ok. 3-4 cm), mniej więcej w połowie ich długości (2,20-3,40 m). Pale podzielono na 5 odcinków, z których pobrano po 3 próbki walcowe (wiercenia rdzeniowe). Głębokości pobrania próbek wynosiły: 0,$33 ; 1,50 ; 2,80 ; 3,87 ; 5,23$ (pal A) oraz 0,$33 ; 1,50 ; 2,70 ; 3,97 ; 5,30$ (pal B). Następnie próbki były przechowywane w laboratorium przez około 30 dni w warunkach stałej temperatury i pełnego nasycenia woda.

\section{BADANIA MODUŁU SPRĘŻYSTOŚCI (YOUNGA) BETONU}

Przebadano próbki walcowe o średnicy $10 \mathrm{~cm}$ oraz wysokości $20 \mathrm{~cm}$. Powierzchnie (górna i dolna) zostały odpowiednio wyrównane i wygładzone przed badaniem. W sumie przetestowano 29 próbek z 30 (1 próbka uległa uszkodzeniu podczas przygotowywania). Próbki betonowe oraz aparaturę badawczą przedstawiono na rysunku 2 i 3 . Do lokalnego pomiaru odkształceń wykorzystano obręcze stalowe o rozstawie $10 \mathrm{~cm}$ oraz 3 indukcyjne czujniki przemieszczenia o dokładności pomiaru $0,001 \mathrm{~mm}$. Obciążenie zadawano ze stałą prędkością w 10 krokach z użyciem maszyny wytrzymałościowej Zwick o maksymalnej sile nacisku $10 \mathrm{t}$.

Przebieg samego badania, czyli zakres zadawanego naprężenia przyjęto według normy PN-EN 12390-13:2014-02. Norma podaje zakres od 0,5 do $0,33 f_{c m}$ $\mathrm{MPa}$, gdzie $f_{c m}$ jest średnią wytrzymałością betonu na ściskanie mierzoną na próbkach cylindrycznych o średnicy $150 \mathrm{~mm}$ i wysokości $300 \mathrm{~mm}$. Dla betonu C30/37 jest to odpowiednio zakres od 0,5 do 9,9 $\mathrm{MPa}$, a rzeczywisty zakres wykorzystany w pracy wynosił od 0,64 do $10,8 \mathrm{MPa}$. Na tej podstawie można było określić normowy moduł sprężystości (styczny). Wartość

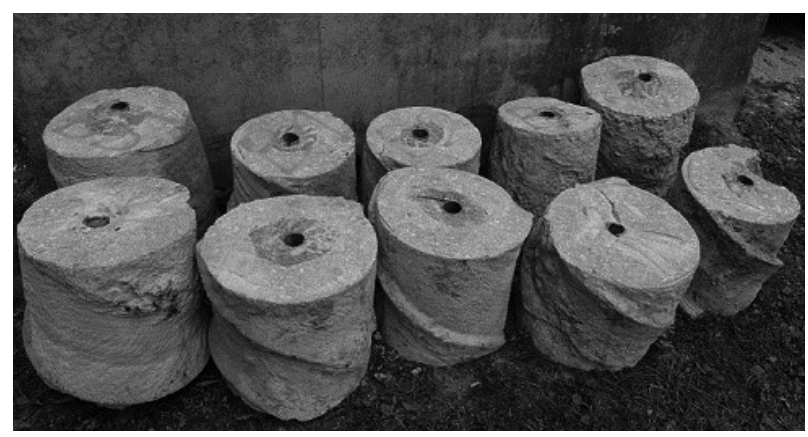

Rys. 1. Pale po wydobyciu $\mathrm{z}$ gruntu oraz wyodrębnione odcinki do badań betonu

Fig. 1. Piles excavated from the ground and particular sections for concrete testing 


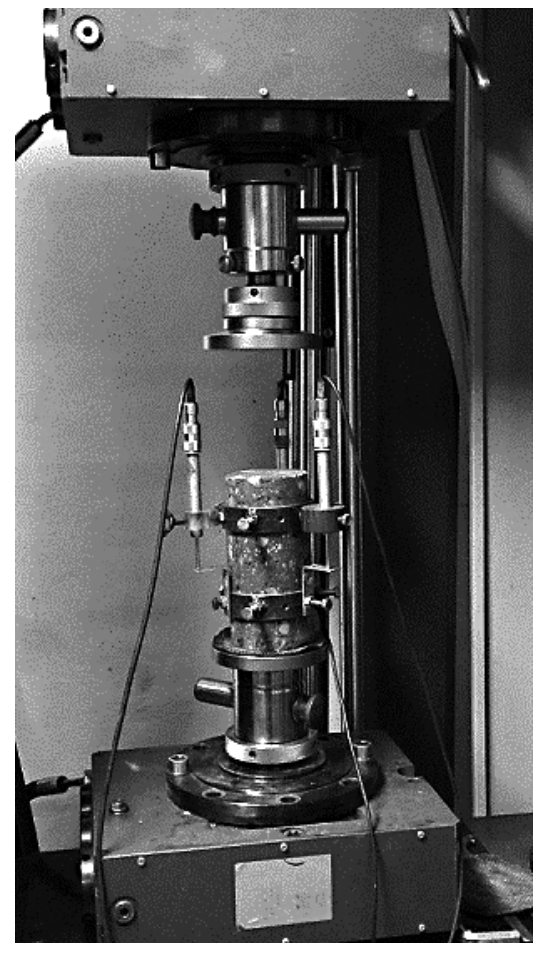

Rys. 2. System pomiarowy odkształceń lokalnych na próbce

Fig. 2. Measurement system for local deformations on the sample

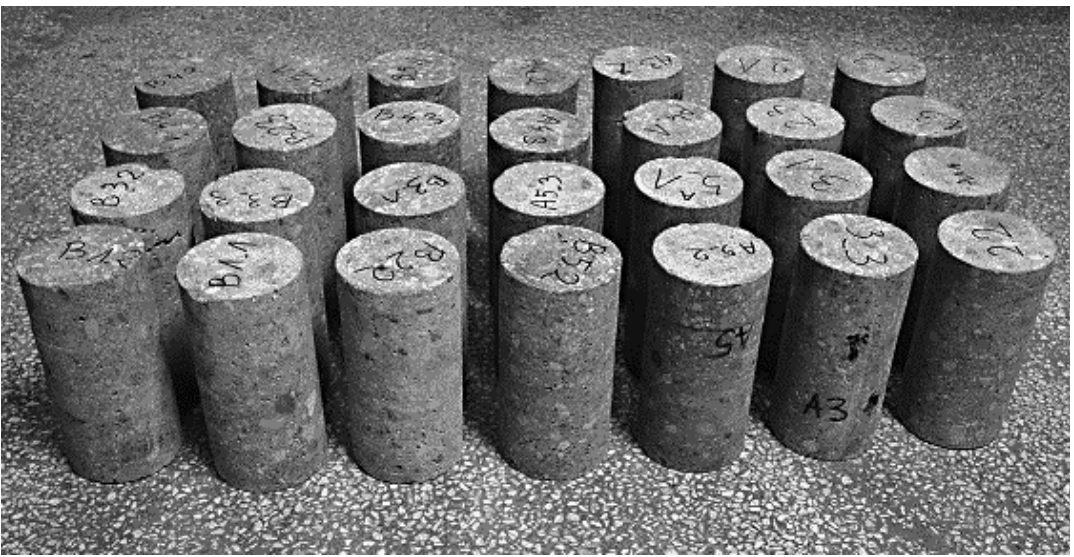

Rys. 3. Walcowe próbki betonu

Fig. 3. Cylindrical concrete samples ta nie odzwierciedla jednak rzeczywistego zachowania się betonu we współzależności naprężenia i odkształcenia $(\sigma-\varepsilon)$. Jak wspomniano wcześniej, moduł sprężystości ulega zmianie wraz z odkształceniem i nie jest to zależność całkowicie liniowa. W związku z tym można wyróżnić następujące rodzaje modułów: $E_{p}-$ moduł początkowy, występujący w zakresie bardzo małych odkształceń i charakteryzujący się znacznie większą wartością niż moduł uśredniony; $E_{s}-$ moduł sieczny, zmienny wraz z odkształceniem; $E_{s t}-$ moduł styczny, który można wyznaczyć dla dowolnego zakresu odkształceń. Zależności te przedstawiono na rysunku 4.

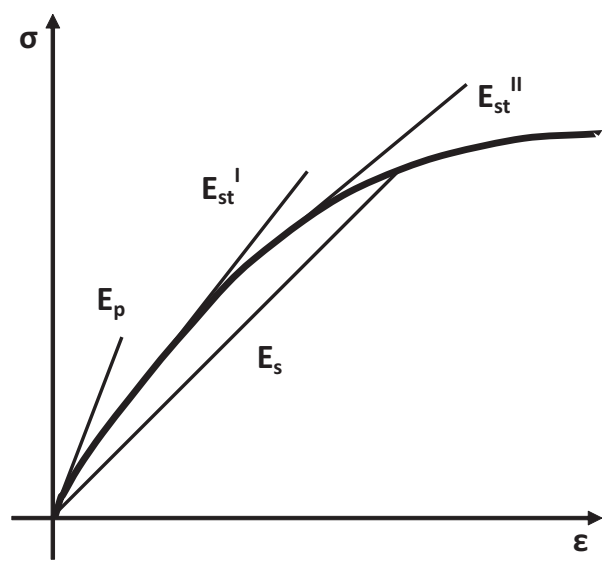

Rys. 4. Możliwe do wyznaczenia wartości modułów sprężystości w zależności od odkształcenia

Fig. 4. Possible values of elasticity modulus regarding to strain level 


\section{ANALIZA WYNIKÓW I DYSKUSJA}

Wyniki badań walcowych próbek betonu zostały przedstawione w formie wykresów $\sigma-\varepsilon$ na rysunku 5 . W obu przypadkach (dla wszystkich próbek) można wyznaczyć dwie strefy, charakteryzujące zachowanie się materiału. W fazie pierwszej (I), dla stałego przyrostu naprężenia rejestrowane są względnie małe wartości odkształceń, co skutkuje dużymi wartościami modułu sprężystości Younga - jest to tzw. moduł początkowy. Wartości te mogą być spowodowane bliżej nieokreśloną właściwością struktury betonu, nierównomiernym rozkładem sił przekrojowych oraz wstępną sztywnością i bezwładnością systemu pomiarowego. Po przekroczeniu około $50 \mu \varepsilon$, nachylenie krzywej $\sigma-\varepsilon$ stabilizuje się, wkraczając tym samym w strefę drugą (II) charakterystyki materiału, w której ma ona przebieg w przybliżeniu liniowy.

Przeprowadzono 29 analiz, 15 dla pala A oraz 14 dla pala B. Z rysunku 5 jednoznacznie wynika niejednorodność badanego materiału - dla tej samej wartości naprężenia osiagnięto różne wartości pomierzonych odkształceń, co jest zwłaszcza widoczne dla pala A. Dla naprezżenia $\sigma=10,8 \mathrm{MPa}$ wartości odkształceń wynoszą od 228 do $336 \mu \varepsilon$, a więc jest to różnica wynosząca 32\%, co bezpośrednio przekłada się wartości modułu sprężystości. Dla pala B różnica ta jest mniejsza i wynosi $12 \%$.

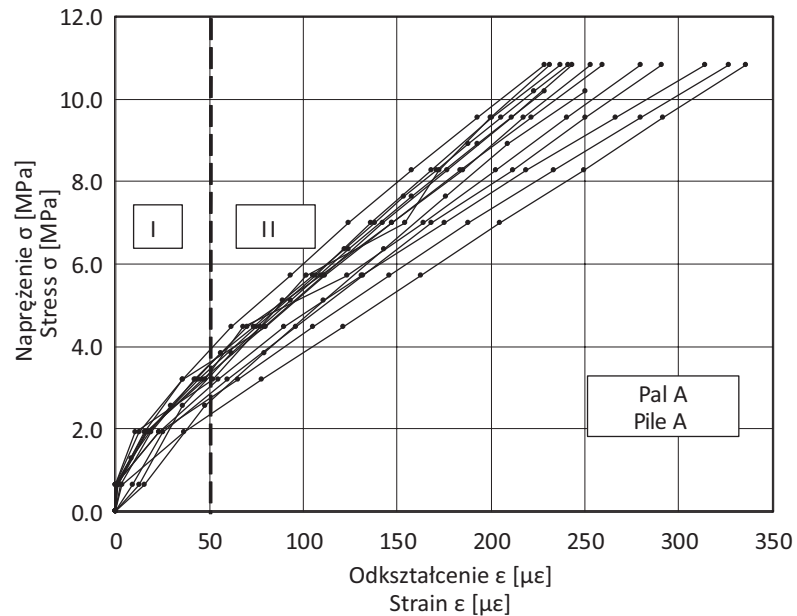

$\mathrm{Na}$ rysunku 6 przedstawiono zmienność modułu siecznego $\left(E_{s}\right)$ w zależności odkształcenia. Zmianę opisano funkcjami potęgowymi dla dwóch pali, odzwierciedlają one dosyć dobrze zachowanie betonu. W zakresie małych odkształceń (do $\varepsilon=100 \mu \varepsilon$ ) moduł $E$ wyraźnie maleje wraz z przyrostem odkształcenia - od wartości 128 do około 50 GPa dla pala A oraz od 112 do około 45 GPa dla pala B. Przy większych odkształceniach (powyżej $100 \mu \varepsilon$ ) moduł dalej systematycznie maleje, jednak już znacznie wolniej i zależność tę można określić jako liniowa. Wyniki z badań laboratoryjnych wykazały analogie do terenowych pomiarów modułu betonu, $w$ których stwierdzono podobną współzależność $E-\varepsilon$ dla modułu siecznego, którą również można opisać funkcją potęgową (Krasiński i Sieńko, 2010; Krasiński, 2011).

Metoda modułu siecznego i jego zmienność stwarza pewne problemy interpretacyjne dla późniejszej analizy naprężenia występującego $\mathrm{w}$ danej konstrukcji. Duża zmienność wraz z odkształceniem oraz dodatkowo niejednorodność materiału na długości pala (szczególnie rozrzut wyników w zakresie małych odkształceń) mogą generować znaczne błędy przy szacowaniu sił przekrojowych $\mathrm{w}$ początkowej fazie obciążenia pala. Konieczne jest więc stosowanie metody umożliwiającej dokładniejszą charakterystykę zachowania się betonu. Według normy krajowej początkowe pomiary (do wartości $\sigma=0,5 \mathrm{MPa}$ ) nale-

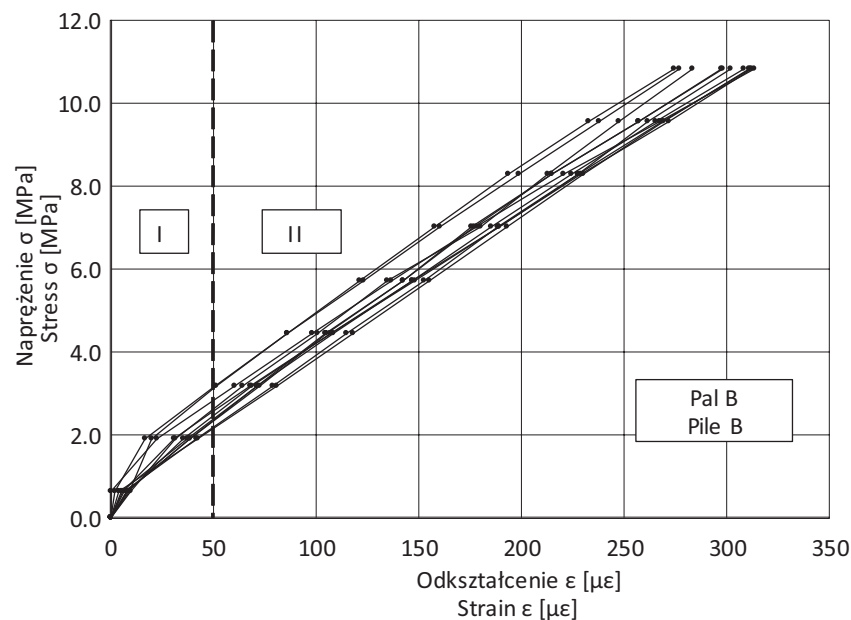

Rys. 5. Współzależność naprężenia i odkształcenia $(\sigma-\varepsilon)$ dla pali A i B

Fig. 5. Piles A and B correlation between stress and strain $(\sigma-\varepsilon)$ 
Wiszniewski, M., Krasiński, A., Linowiecki, J. (2018). Zmienność modułu sprężystości betonu w trzonie pala przemieszczeniowego w świetle badań laboratoryjnych. Acta Sci. Pol. Architectura, 17 (3), 57-65. doi: 10.22630/ASPA.2018.17.3.29

ży pominąć. W przypadku analizowanego materiału wartość ta była niewystarczająca. Charakterystyka $\sigma-\varepsilon$ stabilizowała się w przy odkształceniu $10-36 \mu \varepsilon$ (pal A) oraz 17-39 $\mu \varepsilon$ (pal B), co odpowiadało naprężeniu równemu 2,0 MPa. Mogło to być częściowo spowodowane zbyt dużym skokiem przyrostu naprężenia, przy gęstszej siatce pomiarowej może udałoby się uzyskać stabilizację przy nieco mniejszej wartości naprężenia.

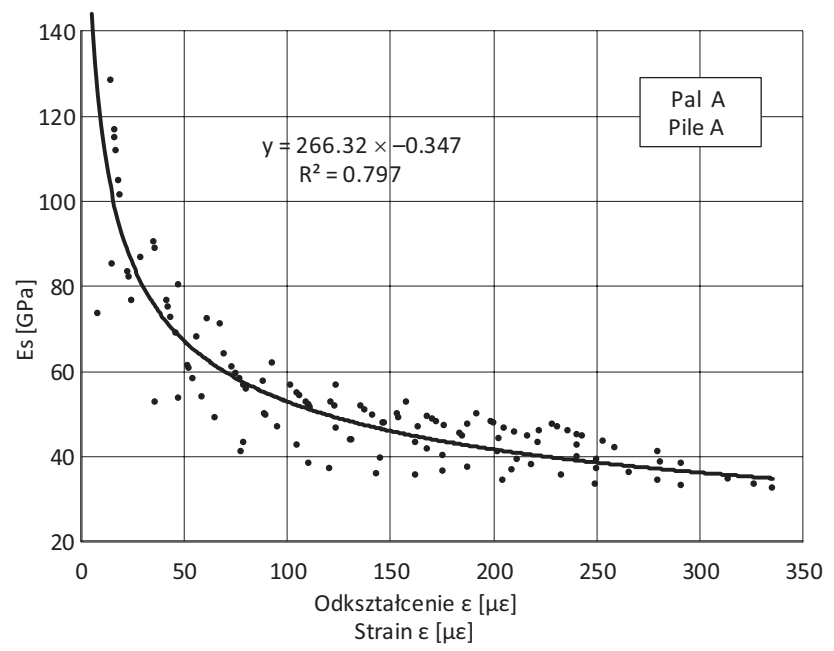

Rys. 6. Rozkład siecznego modułu sprężystości $\left(E_{s}\right)$

Fig. 6. Distribution of secant modulus of elasticity $\left(E_{s}\right)$

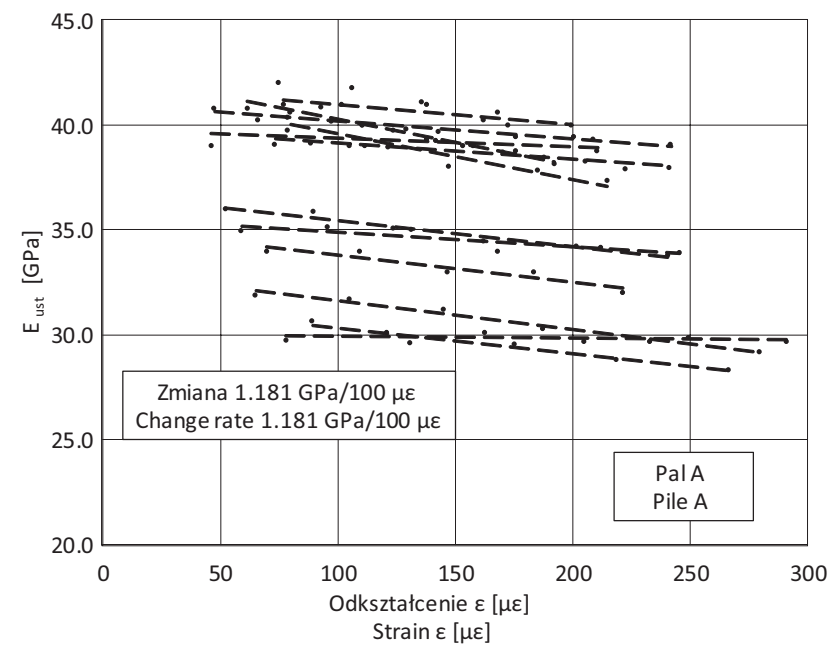

W dalszej analizie ujęte zostały tylko wyniki powyżej $50 \mu \varepsilon$ (strefa II - rys. 5). Dla każdej próbki, rozpoczynając od wartości około $50 \mu \varepsilon$ (mniejsze wartości odrzucono), wyznaczony został nowy rozkład „ustabilizowanego" modułu siecznego $\left(E_{u s t}\right)$ oraz jego zmienność w zależności od odkształcenia (odkształcenia całkowitego uwzględniającego również strefę początkową). Wyniki przedstawiono na rysunku 7. Otrzymano także pewien rozrzut wyników w odnie-

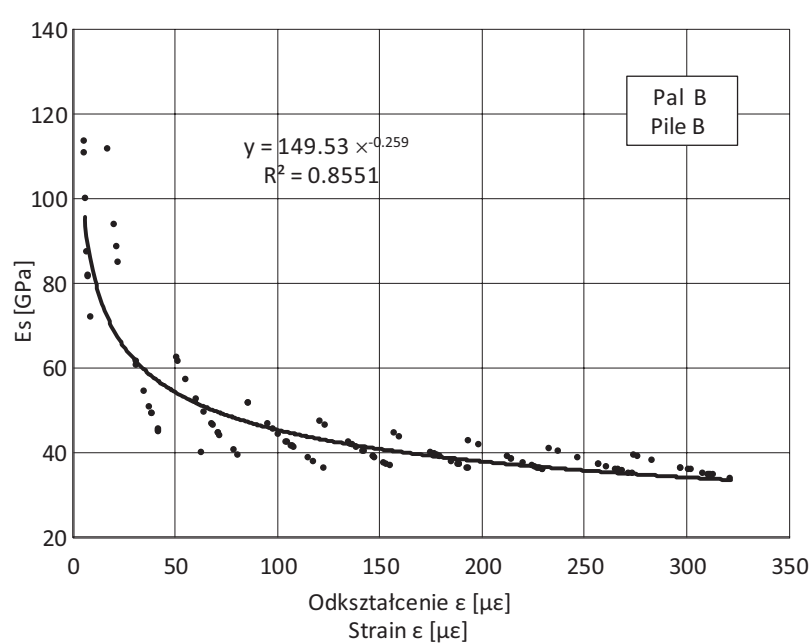

Rys. 7. Rozkład „ustabilizowanego” siecznego modułu sprężystości $\left(E_{u s t}\right)$

Fig. 7. Distribution of the "stabilized" secant modulus $\left(E_{u s t}\right)$

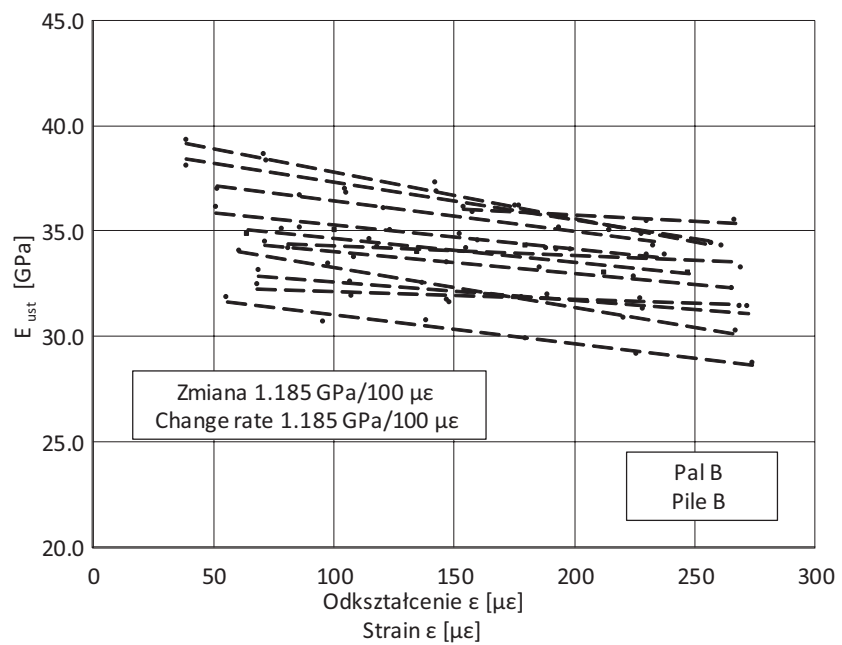


Wiszniewski, M., Krasiński, A., Linowiecki, J. (2018). Zmienność modułu sprężystości betonu w trzonie pala przemieszczeniowego w świetle badań laboratoryjnych. Acta Sci. Pol. Architectura, 17 (3), 57-65. doi: 10.22630/ASPA.2018.17.3.29

sieniu do poszczególnych próbek, ale jest on znacznie mniejszy - dla pala A wartości początkowe modułu dla poszczególnych próbek wynoszą od 30 do $42 \mathrm{GPa}$, a dla pala B od 32 do $39 \mathrm{GPa}$. Co jest istotniejsze, w takim sposobie analizowania zmienność modułu siecznego jest dużo mniejsza i wynosi średnio $2,5 \mathrm{GPa}$ na około $210 \mu \varepsilon$ (porównując do wcześniejszych ponad $10 \mathrm{GPa}$ na $250 \mu \varepsilon)$. W dodatku zmienność tę można opisać zwykłą funkcją liniową przy zachowaniu wysokiego współczynnika korelacji wyników. W obydwu przypadkach (pal A i B) otrzymano podobną średnią charakterystykę tej zmienności - 1,181 oraz $1,185 \mathrm{GPa}$ na $100 \mu \varepsilon$. Stosowanie normowej zasady o pominięciu początkowych pomiarów (początkowego modułu sprężystości) w analizie wyników wydaje się być uzasadnione. W normie nie ma jednak informacji o zmienności modułu wraz $\mathrm{z}$ odkształceniem, a zależność ta może mieć istotne znaczenie przy interpretacji pomierzonych wartości w badaniach pali. Fellenius (2001) w swojej pracy dotyczacej rozkładu sił w palu pisał o ignorowaniu pomiarów mniejszych niż $100 \mu \varepsilon$ przy wyznaczaniu modułu $E$. Jego zdaniem są one obarczone zbyt dużymi błędami i dają nierzeczywiste wyniki. Mimo to niezbedne jest jednak określenie właściwej wartości modułu również w zakresie małych odkształceń. $\mathrm{W}$ przypadku badań pali naprężenia przekazywane na pal maleją wraz z głębokością, powodując coraz mniejsze odkształcenia. Zatem przy podstawie pala częste jest występowanie bardzo niewielkich odkształceń. Aby prawidłowo wyznaczyć rozkład naprężenia (sił), niezbędna jest również znajomość modułu Younga w tym zakresie, a ta szacowana na podstawie ogólnego modułu siecznego potrafi znacznie różnić się na długości pala.

Dla wszystkich 29 próbek w strefie II współzależności $\sigma-\varepsilon$ (rys. 5), a więc z pominięciem pomiarów odkształceń mniejszych niż $50 \mu \varepsilon$, wyznaczono uśredniony moduł sprężystości (moduł styczny dla rozpatrywanego zakresu odkształceń). Literaturowa wartość modułu dla betonu klasy C30/37 wynosi 32-33 GPa. Wartości modułów stycznych otrzymanych $\mathrm{z}$ badań przedstawiono $\mathrm{w}$ tabeli. W obydwu przypadkach, wartości modułu są niejednorodne na długości pala i wynoszą od 28,8 do $39,1 \mathrm{GPa}$ dla pala A oraz od 30,3 do 34,3 GPa dla pala B. Wartości na podobnych głębokościach różnią się średnio
Tabela. Wartości uśrednionego modułu sprężystości $(E)$

Table. $\quad$ Values of the average modulus of elasticity $(E)$

\begin{tabular}{|c|c|c|c|c|c|c|}
\hline \multicolumn{4}{|c|}{ Pal A } & \multicolumn{3}{|c|}{ Pal B } \\
\hline \multicolumn{4}{|c|}{ Pile A } & \multicolumn{3}{|c|}{ Pile B } \\
\hline Lp. & $E$ & $E_{s r}$ & $z$ & $E$ & $E_{s r}$ & $z$ \\
\hline No & [GPa] & {$[\mathrm{GPa}]$} & {$[\mathrm{m}]$} & [GPa] & [GPa] & {$[\mathrm{m}]$} \\
\hline \multirow{3}{*}{1} & 38,0 & \multirow{3}{*}{37,0} & \multirow{3}{*}{0,33} & 34,9 & \multirow{3}{*}{34,2} & \multirow{3}{*}{0,33} \\
\hline & 38,8 & & & 33,5 & & \\
\hline & 34,1 & & & - & & \\
\hline \multirow{3}{*}{2} & 33,8 & \multirow{3}{*}{34,9} & \multirow{3}{*}{1,5} & 33,0 & \multirow{3}{*}{33,2} & \multirow{3}{*}{1,5} \\
\hline & 38,2 & & & 32,0 & & \\
\hline & 32,7 & & & 34,6 & & \\
\hline \multirow{3}{*}{3} & 28,3 & \multirow{3}{*}{28,8} & \multirow{3}{*}{2,8} & 31,5 & \multirow{3}{*}{30,3} & \multirow{3}{*}{2,7} \\
\hline & 28,6 & & & 31,4 & & \\
\hline & 29,6 & & & 28,1 & & \\
\hline \multirow{3}{*}{4} & 38,5 & \multirow{3}{*}{37,7} & \multirow{3}{*}{3,87} & 37,7 & \multirow{3}{*}{34,3} & \multirow{3}{*}{3,97} \\
\hline & 33,7 & & & 35,0 & & \\
\hline & 40,7 & & & 30,2 & & \\
\hline \multirow{3}{*}{5} & 39,7 & \multirow{3}{*}{39,1} & \multirow{3}{*}{5,23} & 33,9 & \multirow{3}{*}{32,8} & \multirow{3}{*}{5,3} \\
\hline & 37,1 & & & 31,0 & & \\
\hline & 40,5 & & & 33,4 & & \\
\hline
\end{tabular}

o 6,5\% (dla ostatniego odcinka różnica ta wynosi $16,2 \%)$. Należy zwrócić uwagę na obniżoną wartość modułu $E$ (28,8 oraz $30,3 \mathrm{GPa})$ na głębokości około 2,80 m, zarówno dla pala A, jak i pala B. Na tej głębokości stwierdzono również niewielkie przewężenie trzonu. Pale znajdowały się w odległości od siebie około 2,0 m, a więc wykonane były w praktycznie identycznych warunkach gruntowych. Przewężenie wystapiło w warstwie ściśliwego namułu nasyconego woda. Jego przyczyną mogło być zwiększone parcie warstwy namułu na świeży beton i tendencja otworu palowego do częściowego zamykania się. Proces ten mógł być rozłożony w czasie i naruszyć strukturę dojrzewającego betonu.

Amir i inni (2014) wykazali w swojej pracy, że moduł sprężystości betonu $\mathrm{w}$ palu wzrasta wraz 
z głębokością. W analizowanym przypadku ciężko jest jednoznacznie stwierdzić taką zależność. Należy podkreślić, iż w cytowanej pracy długość pali wynosiła $70 \mathrm{~m}$ oraz autorzy dysponowali większą liczbą danych, co pozwoliło na dokładniejsze scharakteryzowanie materiału. $\mathrm{Z}$ całą pewnością można jednak stwierdzić zmienność modułu na długości pala i powinna być ona uwzględniania przy analizie i interpretacji pomiarów odkształceń trzonów pali betonowych.

\section{WPŁYW MODUŁU SPRĘŻYSTOŚCI NA INTERPRETACJĘ POMIARÓW PODCZAS PRÓBNYCH OBCIAŻ̇EŃ PALI}

Wykorzystując oszacowane wartości modułu sprężystości, można wyznaczyć sztywność danego elementu, a następnie na podstawie pomierzonych odkształceń określić siły przekrojowe. Metodę tę stosuje się m.in. przy ustalaniu współpracy pala z gruntem, czyli określaniu jednostkowego tarcia na pobocznicy dla poszczególnych warstw gruntu. Przyjmowanie jednej, stałej wartości modułu na całej długości pala może doprowadzić do znacznych błędów przy szacowaniu rozkładu sił. Przykładowo przyjmowanie modułu większego niż $25 \mathrm{GPa}$ powoduje nierealnie duże wartości siły (większe niż zadane na głowicy). W górnej części pala występują największe odkształcenia, więc zgodnie z wcześniejszymi ustaleniami moduł osiagnie tutaj najmniejszą wartość. Odwrotna sytuacja zachodzi przy podstawie pala, gdzie po pierwsze moduł może osiągnąć większą wartość ze względu na głębokość zalegania, a po drugie wystąpią tutaj najmniejsze odkształcenia (możliwe, że mniejsze od $50 \mu \varepsilon$, a więc $\mathrm{w}$ zakresie dużych wartości modułu początkowego). Dla stałej wartości modułu sprężystości 25 i 45 GPa siły w podstawie pala wynoszą odpowiednio od 121 do $198 \mathrm{kN}$, a więc różnica $\mathrm{w}$ rozkładzie przejmowania siły pionowej poprzez pobocznicę oraz podstawę pala wynosi $68 \%$. Niemożliwe jest jednak każdorazowe pobieranie próbek betonu na całej długości pala w celu ustalenia dokładnej wartości modułu. Autorzy stosują tzw. metodę iteracyjną określenia jego zmienności na długości pala, która pozwala częściowo wychwycić zmiany przekroju oraz niejednorodności materiału pala. Metoda ta jest jednak nadal testowana i nie została jeszcze opublikowana. Autorzy dalej pracują nad poprawieniem istniejących rozwiązan. Stosowana jest również metoda Felleniusa (1989) Tangent Modulus Method do wyznaczania modułu betonu, która wymaga jednak osiagnięcia dużych odkształceń w poszczególnych odcinkach trzonu pala oraz znacznych przemieszczeń całego pala w celu osiagnięcia pełnej mobilizacji tarcia na pobocznicy. Stosowalność tej metody w wielu sytuacjach jest zatem ograniczona.

\section{WNIOSKI}

Po przeanalizowaniu wyników oraz na podstawie wcześniejszych obserwacji można sformułować następujące wnioski:

- wartość modułu sprężystości betonu zależy od wielu czynników, m.in. od czasu i warunków dojrzewania, dlatego powinna być wyznaczana dla każdego analizowanego materiału i nie może być przyjmowana $\mathrm{z}$ tablic na podstawie deklarowanej klasy wytrzymałości na ściskanie;

- przy badaniu próbek betonu w laboratorium bądź fragmentów konstrukcji w pomiarach terenowych można wyznaczyć 2 strefy zachowania się materiału w współzależności $\sigma-\varepsilon$. Pominięcie strefy początkowej sztywności umożliwia ustalenie w miare jednorodnej, liniowej charakterystyki materiału;

- moduł $E_{b}$ jest zależny od odkształcenia, maleje wraz z jego wzrostem. Dla strefy II (ustabilizowanej) określono liniowy spadek na około $1,18 \mathrm{GPa}$ na $100 \mu \varepsilon$;

- badania potwierdziły również niejednorodność materiału (modułu betonu) na długości pala, stwierdzono w przypadku obu pali osłabienie w miejscu przewężenia przekroju. Analizowane pale były zbyt krótkie, aby jednoznacznie ocenić wzrost modułu $E$ wraz z głębokością opisywany w niektórych pozycjach literatury;

- przyjmowanie stałej wartości modułu betonu do interpretacji odkształceń pomierzonych $\mathrm{w}$ palu może prowadzić do znacznych błędów w szacowaniu wartości sił przekrojowych. 


\section{ADNOTACJA}

Projekt został częściowo sfinansowany ze środków Wydziału Inżynierii Lądowej i Środowiska PG w ramach funduszy DS dla Młodych Naukowców.

\section{PODZIĘKOWANIA}

Autorzy pragną złożyć podziękowania dla Pana Piotra Kanty z firmy Menard Polska za pomoc w realizacji zadania badawczego, wsparcie techniczne i materialne przy organizowaniu poletka doświadczalnego oraz dla Pana Eugeniusza Grzesia z Katedry Budownictwa i Inżynierii Materiałowej PG za pomoc w przygotowaniu próbek betonu do badań.

\section{PIŚMIENNICTWO}

Ali, F.H. i Lee, S.K. (2008). A New Instrumentation Method for Driven Prestressed Spun Concrete Piles. The Electronic Journal of Geotechnical Engineering, 13, 1-12.

Amir, J.M., Amir, E.I. i Lam, C. (2014). Modulus of elasticity in deep bored piles. W DFI/EFFC International
Conference on Piling and Deep Foundations, Stockholm.

Fellenius, B.H. (1989). Tangent modulus of piles determined from strain data. W The ASCE Geotechnical Engineering Division Foundation Congress. T. 1 (strony 500-510).

Fellenius, B.H. (2001). From Strain Measurements to Load in an Instrumented Pile. Geotechnical News Magazine, 19 (1), 35-38.

Kiefer, T.A. i Baker, C.N. (1994). The effects of free fall concrete in drilled shafts. Report to FHWA-ADSC, STS Consultants Ltd., Northbrook.

Krasiński, A. i Sieńko, R. (2010). Wykorzystanie pomiaru pionowego rozkładu siły w palu do interpretacji testów statycznych. Magazyn Autostrady, 11, 24-28.

Krasiński, A. (2011). Wyniki badań terenowych pali i kolumn wkręcanych. Inżynieria Morska i Geotechnika, 32 (6), 516-529.

Justs, J., Bajare, D., Shakhmenko, G. i Korjakins, A. (2011). Ultra high performance concrete hardening under pressure. W Proceedings of the $3^{\text {rd }}$ International Scientific Conference: Civil Engineering, Jelgava (strony 38-43).

PN-EN 12390-13:2014-02. Badania betonu. Część 13: Wyznaczanie siecznego modułu sprężystości przy ściskaniu.

\title{
LABORATORY TESTS ON CONCRETE ELASTIC MODULUS VARIATION IN DISPLACEMENT PILE
}

\begin{abstract}
The paper presents problems concerning the determination of material properties of concrete in order to interpret the results of static load tests on instrumented piles. Laboratory tests of elastic modulus of concrete $\left(E_{b}\right)$ were carried out on particular sections of displacement piles extracted from the ground. Characteristics of elastic modulus variability with strain and depth were determined. Twenty nine samples from five different depths were tested. The paper presents methods for estimating the actual value of the concrete modulus. Influence of adopted material properties on the interpretation of static load test on instrumented pile is also presented.
\end{abstract}

Key words: concrete Young's modulus, foundation piles, strain measurement, pile instrumentation 